ACTA UNIVERSITATIS LODZIENSIS

FOLIA LITTERARIA POLONICA 7(37) 2016

http://dx.doi.org/10.18778/1505-9057.37.09

Marzena Woźniak-Łabieniec*

\title{
Censorship as a Taboo during Political "Thaw"
}

Already in January 1946, during a briefing of the chiefs of Main Office of Control of Press, Publications and Shows (GUKPPiW), it was stressed that it was necessary to uphold the prestige of the censor and the entire Bureau ${ }^{1}$. One of the methods for fulfilling this proposition was to remove from any publication all references not only to the activities of GUKPPiW but also to its existence. However, concealing censorship's existence was mainly a result of the policy of the state which strived to maintain the illusion of democracy. This situation remained unchanged throughout the first post-WWII decade, as confirmed by hundreds of examples found in censorship documents.

The situation started to change slightly during the thaw. In the late-1955, there appeared the first signs of cracks in the wall of silence surrounding the Bureau's servient attitude to the Party. For a limited time, censors became more liberal, and one might draw from their mode of marking the interventions that many of them began to second guess their decisions. An example was an extensive review by Flaszen, published in Życie Literackie, of Lem's trilogy entitled Czas nieutracony [Time Not Lost] published therein. Hospital of the Transfiguration, the first part of the series, was supposed to be published in 1949 by the Gebethner \& Wolf Publishing House but it was halted by the censorship ${ }^{2}$. Already in the first paragraph Flaszen asked why so much time had to pass between the completion of the book and its publication:

The typescript was tossed between the desks of publishing houses for five years (...) begging editors for mercy and understanding, occupying the heads and minds of internal reviewers. (...) What held the hand of publishers for so long from signing the book's release for print? What terrible venom would Lem pour into the law-abiding nature of the civil frame of mind?

* Dr hab., e-mail: marzenaw@uni.lodz.pl; The University of Lodz, Faculty of Philology, Department of the Polish Literature of $20^{\text {th }}$ and $21^{\text {st }}$, 90-236 Łódź, ul. Pomorska 171/173.

${ }^{1}$ AAN (the Archive of New Records), GUKPPiW, ref. no. 421/vol. 2, 1. 103.

${ }^{2}$ Lem's struggles with censorship at the beginning of his creative life were discussed in detail by Kamila Budrowska, cf. idem, Literatura i pisarze wobec cenzury PRL 1948-1958, Białystok 2009, pp. 148-178. 
He did not refer to the activities of censorship directly but rather constructed his text in such a way for the typical reader of a literary journal to understand that it was censorship to which he was referring. Further, there was an ironic fragment removed by the first censor:

Mental asylum? There are no such places. Decadent love for psychopathology, bourgeois peculiarities, atypical. Violation of law and order by national security institutions? There were none. Meditation over life and death? Indecisiveness of the intelligentsia, there is no God, there is no soul, there is only the class struggle, there is no death. World-view anxiety? We know everything, the world is mere matter, thought - highly-organised matter. Unhappy love? There is no such thing. Socialism solves all human personal problems. Moral question marks? There are none and there cannot be any, morality can only have objective criteria. And on top of that decadence, psychologism, naturalism, formalism, aestheticism, behaviourism, free indirect speech, metaphysical murkiness, bourgeois putridity. Secretly: oh, how great and deep this is, and how bold, and what excellent psychological analyses! An in an undertone: dangerous, spreading confusion in the minds of simple readers. Decision: do not publish ${ }^{3}$.

Even though the author again refrained from stating any specific institution responsible for rejecting the book (he only reconstructed a certain mode of thinking), the censor considered that fragment as offensive, thus justifying the intervention:

The reason why the above paragraph was removed was its ironic attitude towards the previous period, in which Flaszen perceived only some wrong aspects, which included the falseness of certain operating criteria and the forms of thinking not only within literature and arts, but also in political life. The destructive nature of this also lies in the fact that all the indicated flaws Flaszen utters in one gulp 4 .

That censor defined the intervention as favourable (mind you: not "necessary" anymore but only "favourable"), while the second control officer defined it as "redundant-nosy". Eventually, the removed fragment was replaced with a tempered one, though carrying a high emotional load:

No, I absolutely cannot fathom how it could have happened that Czas nieutracony became a publishing problem. I somewhat know why, but I cannot understand that. I do not. The nuances of hardened doctrine-defined justifications vanished; what is

\footnotetext{
${ }^{3}$ AAN, GUKPPiW, ref. no. 412 (37/7), 1. 97.

${ }^{4}$ Ibidem.
} 
left is pure nonsense, a blend of ridiculous theoretical tricks. We should not try to understand nonsense because all we will get is dread. If we do not understand it, that's good as it is a certain sign that we ourselves are already outside of it ${ }^{5}$.

Flaszen highlighted how the delay in the publication negatively affected the novel's reception. He stressed that if it been published right after it was written, it would have had been a hit; perfectly matching the contemporary debate on the schematic manner in the behaviour of his opponents. Today it seems an outdated "fossil from a past era"

Six months later, the June issue of Nowa Kultura included a very similarly constructed review (of Rojsty by Konwicki this time) by Roman Zimand. The article's title itself was significant: Dlaczego nie osiem lat temu? [Why not eight years ago?]. Zimand wrote about the so-called drawer novels (e.g. he revisits Lem's Time Not Lost). His argumentation moves to show how much the novel Rojsty had lost while lying in the drawer, how much more interesting and current it would had been if it had been published in the late 1940s. He also wrote directly about censorship:

“(...) using this book as an example I wish to trace, to catch red handed that system of thinking which delayed the publication of the novel début by eight years.

(...) the main reason lied in the actual phrase "Vilnius Home Army". The practical assumptions of contemporary propaganda were as follows: do not speak about difficult issues. Pretend they do not exist. And the issue of Lithuania-Belarus land must have been a rather difficult one ${ }^{7}$.

Zimand referred to such an approach as the "Great Ostrich" approach (to bury one's head in the sand), behind which was the intention: let us avoid painful issues, let us wait, maybe in 10 years' time people will no longer be interested in the problem (when the readers "will have the same attitude to the Home Army guerrilla squads in the Vilnius region as to the Wallonia separatists"), then we will consent to Rojsty's publication.

Consider how Zimand referred to the problems: he did not write about the Polish United Workers' Party or the Control Bureau, instead he used generalisations (the contemporary "system of thinking") or metaphors ("the Great Ostrich"). Nonetheless, both critics drew readers' attention to an important problem: how, by considerably delaying the publication of controversial texts, the censor's control and interventions caused the books to miss their time. Many of the works halted in such a way never again saw the light of day as either the only copies of

\footnotetext{
${ }^{5}$ L. Flaszen, Czas rzeczywiście nieutracony, “Życie Literackie” 1955, issue 50 (11 XII), p. 7.

${ }^{6}$ Ibidem.

${ }^{7}$ R. Zimand, Dlaczego nie osiem lat temu?, "Nowa Kultura” 1956, issue 25 (17 VI), p. 6.
} 
typescript were returned by the Bureau or, after many years had passed, when they could finally be published, their authors themselves decided not to do that as they understood their works had ceased to be current.

Less than two weeks after the publication of Zimand's article the Warsaw censorship Bureau received an article by Andrzej Braun submitted with Nowa Kultura bearing the blusterous title: Na jakim świecie żyjemy? [What kind of a world do we live in?] Braun drew readers' attention to yet another problem associated with the operations of censorship which distorted any debate by hindering free exchange of views. He also refrained from identifying the institutions responsible for the situation and this time used spiritualist vocabulary:

Who is guilty? Some elusive spirits co-editing our articles. Yet another example of the mysterious witchcraft, secret forms of discussion and clashes of different views which when printed take the form of utter mess, imposing somebody else's opinions, an anonymous backstage confusion of the readers.

Dear comrade editor. I wish to protest against the influence of anonymous forces, which make writers liable, which hide underneath the shade of their names, against the supernatural practices of faceless decision-making. I wish to protest against forcing me to feel solidarity with a sentence which is not mine, to putting me in a difficult and de-mysticised situation of discussions in someone else's name. I wish to protest against the unfair charges which incriminate me which are a result of a misunderstanding. In the name of lawfulness, clarity of debate and common sense ${ }^{8}$.

Initially, in the report card, the censor did not delete this rather strong fragment but only marked it on the side with a vertical red line as if he was considering whether to delete it. Eventually, the article was edited and the title was toned down (from a title suggesting that the world we live in is not the best one there is to a title criticising not the reality but politics: Politics - a dirty matter). Interestingly enough, after being edited the article does not refer directly to harming the debate, yet the censor does, surprisingly (probably as a result of an oversight), allow the name of the Bureau to be stated, though it appears between an accumulation of spiritualist metaphors while the censor's desk seems as a rotating table during a ghost summoning session:

"The sleep of reason produces monsters". So many monsters have been born that they
have blacked out the sun over our motherland (...) We wish to break away from the
danger of the Middle Ages repeating themselves, from mythology and magic, from
inquisition, exorcisms, degrees of initiation and witch trials. (...) We are still under
the influence of those magical articles. One of those is a principle that anything that

${ }^{8}$ AAN, GUKPPiW, ref. no. 485 (38/14), 1. 56. 
has not been said, does not exist. And that said in the public sense, p r i n t e d. Hilarious, isn't it? - and yet... The fact that it applies to facts, that people know about it, they think, they talk among themselves, that we can all see that means nothing. In these policies human thought is not something to be considered. We make our agreements in silence. We make fools of each other. (...)

For example, following the view of the world presented in printed publications (excluding the phone book) one could assume that the Press Control Bureau, i.e. the so-called censorship, does not exist in our country. The spirit has not yet materialised and only through the fragmented progress of sentences in some articles does it indirectly reveal its existence and activity. If the reader finds at this point of the column proof that something is missing, she or he should understand: thus spoke the floating table so that the hit dog hollered. Jokes? - yes, jokes. But wouldn't it be better to instead of hiding the existence of some of our institutions which are supposed to support the revolution openly admit they exist and overtly analyse how they serve it ${ }^{9}$.

To support his position and appease censors Braun referred to. Lenin, who made a juxtaposition of free revolutionary literature against bourgeois literature, which concealed its servient role towards the class of owners. Braun indicated the danger of expanding the themes banned under the pretence of maintaining state or military secrets. Thus, the silence surrounding abuse, theft, wastefulness and violence is justified.

The act of referring to the ideologists of the new faith was a common journalistic trick which was utilised to put control bureau officers off guard. A similar trick was used two months later by Julian Przyboś, who directed the sting of Marxism towards Socialist realism and the ridiculed slogans still lingering, regardless of the thaw, in literary journals. Przyboś stated that when the times demand grand journalism the voices of "minimalistic fixer-bureaucrats" are not enough. Marxism was "the most critical research focus that does not accept any fixed truth unless it is the truth of continuous variation of that which incessantly changes while it exists" "10. Marx's ideals did not, however, seem a sufficient justification as the censor "shreds" the text removing fragments that reveal not only the power of the censors but also their incompetence (removed fragments are struck out):

Dictated, passed, binding, sole! Socialist realism was not a trend or, as it was propagated, a creative method, socialist realism was a politieal and eensorship supervision over literattre, it was pressure (...), a "stage" tactics, and the taeties were defined by Party offieers. They eould just as well have the same idea about literature and art as a ehieken about pepper, but if only they were positioned high enough, there was

\footnotetext{
9 "Nowa Kultura" 1956, issue 27 (1 VII), p. 2.

${ }^{10}$ J. Przyboś, Dyskusja..., "Nowa Kultura” 1956, issue 36 (2 IX), p. 3.
} 
no appealing their sentenee (Was the banned Lament papierowej glowy by Andrze= jewski even released in print? $)^{11}$

The direction of the intervention is something worth noticing. The censor removed the expression "Party officer" and did not allow him to be accused of incompetence. He replaced the ad personam reference with a much broader and non-personal reference writing of "bureaucratic pressure" exerted on writers "in order for them not to even dare think differently than as it was required by the tactics of the "stage"12. The censor was able to leave many strong accusations (thus creating a type of a safety valve) as long as they were directed towards anonymous non-personal forces or when the GUKPPiW was blamed for the interventions, not other decision-making entities, which is visible in the following fragment left by the censor:

Any debate in sections was not possible, there applied the specific "baitism", i.e. waiting for someone to carelessly reveal themselves with some idea and a collective abetting against the victim. (...)

Therefore, sections were to function as the first filter of the multilayer system of censorship; union journals were the second, book publishing houses the third (sometimes the order was reverse: what was allowed in a book was later halted by the editorial censorship filter), and Press Control was the fourth. The most important function of an editor-in-chief was to fulfil the recommendations of the propaganda bureau. Bureaucratisation of literature was becoming a fact; the more zealous writers transformed into propaganda bureau officers, becoming even more official, and by having in their hands the Union board and managing journals they became untouchable ${ }^{13}$.

Interestingly enough, when the censor read about the consecutive levels of control: ZLP (Polish Writers' Union) divisions, the publishing house, and editorial censorship, he was not alarmed. However, when there was a mention of the fourth level: control of press, seeing that it referred to an institution he himself represented, he carefully marked the fragment underlying it in red. He eventually decided not to intervene, though, maybe because the allusion was not developed further and Przyboś returned to accusing the level of magazine editorial boards and the management of ZLP.

In the autumn of 1956, under the influence of political events, there was an increase in the number of demands for freedom of speech, usually removed, par-

\footnotetext{
${ }^{11}$ AAN, GUKPPiW, ref. no. 485 (38/14), 1. 36-37.

12 J. Przyboś, Dyskusja o związu literatów, p. 7.

${ }^{13}$ AAN, GUKPPiW, ref. no. 485 (38/14), 1. 37.
} 
ticularly from magazines - of Party institutions or literary journals - of ZLP institutions, such as a fragment of an article by Ważyk in Nowa Kultura, a in which the names of the Bureau and a demand for lifting censorship was removed ${ }^{14}$ :

Freedom of speech and freedom of literary creation will never be guaranteed unless the Sejm issues a clear press act in accordance with the spirit of the Constitution and UKPPiW is abolished ${ }^{15}$.

The demands echoed and were some of the main points during the ZLP Convention between November and December 1956. Many of the participants expressed their strong opposition towards censorship. The press comments and reports from the Convention published at that time show that the censors left the information that writers defended "freedom of speech" but usually removed any evidence of the fact that they also demanded censorship be lifted and the Control Bureau be closed. Thus, the more general expressions not directed towards any specific institutions or persons stood a better chance of being published. An example of this was a series of four articles published in "Expres Poznański" in December 1956 devoted to remarks on the Convention ("Pozjazdowe wrażenia i refleksje" I-IV $)^{16}$. In the above-mentioned articles as well as many other published in the second half of 1956, also after the Convention, censorship often allowed suggestions to expand the contacts with emigrants, Paris-based in particular, and demands for the removal of prohibited items. Demands for the national permit for the distribution of Paris-based Kultura was deleted consistently. An article by Zbigniew Florczak from late-October 1956 in which the censor proposed to replace the demand to offer Kultura a national distribution permit with the proposal for a "wider reach in the country" was symptomatic. Once again: it seemed to mean the same thing but the expression was so general that it did not require any specific changes on the part of the authorities. Florczak expressly wrote about emigration and the London and Paris communities. He mentioned the names of emigre writers while referring to the Paris-based Kultura, he wrote about a visible change in the relationship between the country and the emigrants, and about a less restricted exchange of thoughts, and even disputes. He did not fail to criticise the community stating that it was not able to follow the changes in the country (he considered contemporary national journalism as something

\footnotetext{
${ }^{14}$ A. Ważyk, Dyskusja o zwiazku literatów, "Nowa Kultura”1956, issue 42 (14 X).

${ }^{15}$ AAN, GUKPPiW, ref. no. 485 (38/14), 1. 18.

${ }^{16}$ E. Paukszta, Mądrość i bezkompromisowość [Pozjazdowe wrażenia i refleksje (I)], "Express Poznański” 1956, issue 287 (5 XII), p. 2; Największym wrogiem-tandeta, [Pozjazdowe wrażenia i refleksje (II)], "Express Poznański" 1956, issue 288 (6 XII), p. 2; Sprawy zawodowe, [Pozjazdowe wrażenia i refleksje (III)], "Express Poznański”, issue 289 (7 XII 1956), p. 2; Zginęły uprzywilejowania, [Pozjazdowe wrażenia i refleksje (IV)], "Express Poznański” 1956, issue 290 (8 XII), p. 2.
} 
of a much higher level than emigre journalism), yet he demanded a distribution permit for Kultura:

To begin with, I propose that a truly good Polish emigre magazine, the Paris-based Kultura, should be allowed in the country an offeial entry. (...) ff our eensorship thinks that there still are any isstes eoneerning Polish affairs that should be kept seeret, it is a huge mistake on the part of eensorship ${ }^{17}$. (...)

Secondly, the Kultura team, as one might realise, takes its didactic mission seriously and in the event of reeeiving a nationide pulieation permit [instead the censor proposed: "a broader access to the country"] will not risk the embarrassment of any propaganda excesses.

The post-censorship "touch-up" was far less "demanding":

To begin with, I propose that a truly good Polish emigre magazine, the Paris-based Kultura, should be allowed in the country. (...).

The Kultura team, as one might realise, takes its didactic mission seriously and in the event of receiving a broader access to the country shall not risk the embarrassment of any propaganda excesses ${ }^{18}$.

The time of political thaw was a time when journals began to include many topics consistently removed by censorship in previous years. Including those "dangerous" ones which were associated with the functioning of GUKPPiW: the problem of a continued hold on book issues, the so-called "drawer novels", the need to release prohibited items and the issue of the relationships between the country and emigrants, Paris-based in particular. Thanks to the many changes, in censorship instructions, which was a result of relaxing the political hold, many valuable voices were able to appear, particularly in the second half of 1956. Such a censorship policy was possible in the following year of the thaw as well, though it was not always fulfilled consistently, all the way until 1958 when censorship increased considerably and censors removed all demands allowed during the thaw.

\section{Bibliography}

AAN, (the Archive of New Records), GUKPPiW, ref. no. 412 (37/7), 1. 97.

AAN, GUKPPiW, ref. no. 421/vol. 2, 1. 103.

AAN, GUKPPiW, ref. no. 485 (38/14), 1. 18.

AAN, GUKPPiW, ref. no. 485 (38/14), 1. 22.

AAN, GUKPPiW, ref. no. 485 (38/14), 1. 36-37.

AAN, GUKPPiW, ref. no. 485 (38/14), 1. 37.

AAN, GUKPPiW, ref. no. 485 (38/14), 1. 56.

${ }^{17}$ AAN, GUKPPiW, ref. no. 485 (38/14), 1. 22.

${ }^{18}$ Z. Florczak, Znowu - wokót emigracji, "Nowa Kultura" 1956, issue 44 (28 X 1956), p. 2. 
Budrowska Kamila, Literatura $i$ pisarze wobec cenzury PRL, Wydawnictwo Uniwersytetu w Białymstoku. Białystok 2009.

Flaszen Ludwik, Czas rzeczywiście nieutracony, “Życie Literackie” 1955, issue 50 (11 XII).

Florczak Zbigniew Znowu - wokół emigracji, "Nowa Kultura” 1956, issue 44 (28 X 1956).

Przyboś Julian, Dyskusja o związu literatów, "Nowa Kultura” 1956, issue 36 (2 IX).

Ważyk Adam, Dyskusja o związu literatów, "Nowa Kultura” 1956, issue 42 (14 X).

Zimand Roman, Dlaczego nie osiem lat temu?, "Nowa Kultura” 1956, issue 25 (17 VI).

Marzena Woźniak-Łabieniec

\section{Censorship as a Taboo during Political "Thaw"}

\section{(Summary)}

During political “thaw”, in years 1955-1956 in the People's Republic of Poland, it write in newspapers about themes banned earlier. One of such many theme formerly banned was censorship (Main Office of Control of Press, Publications and Shows). Journalists wrote about books banned by censorship, prohibited publications and black-listed writers, whose books had removed from libraries and destroyed. Situation is changed in 1958 - it is not allowed to write again about existence and activity of censorship

Keywords: political "thaw" in years 1955-1956, People's Republic of Poland, censorship after 1945, censorship towards literature 